\title{
Effects of acid/alkali and cellulase enriched mixed enzyme treatments on properties of jute-cotton union furnishing fabric
}

\begin{abstract}
The effects of chemical pre-treatments using dilute acids $\left[\mathrm{HCl}, \mathrm{CH}_{3} \mathrm{COOH}, \mathrm{HCOOH}\right.$, $\left.\left(\mathrm{CH}_{2} \mathrm{COOH}\right)_{2} \mathrm{C}(\mathrm{OH}) \mathrm{COOH}\right]$ and alkali $(\mathrm{NaOH})$ on raw jute and jute-cotton $(75: 25)$ union fabric and the effects of specified mixed enzyme system (different proportion of mixture of cellulase, xylanase and pectinase) pretreatment on conventional $2 \%$ $\mathrm{H}_{2} \mathrm{O}_{2}$ bleached jute-cotton union fabric have been comparatively evaluated. Among different organic/ mineral acid pretreatments $1 \% \mathrm{HCl}$ treatment shows higher surface brightening action than that obtained by formic acid, acetic acid and citric acid pretreatment. All these acid pretreatment do not show desirable softening action but show varying degree of surface leaching action associated with measurable changes in $\mathrm{K} / \mathrm{S}$ value, whiteness, yellowness and brightness indices. However, $10-18 \% \mathrm{NaOH}$ pretreatment of raw jute-cotton union fabric show appreciable softening action but is associated with higher mass loss, appreciable reduction in tenacity and surface darkening. While, $5 \%$ dilute $\mathrm{NaOH}$ pretreatment show somewhat less softening action, but exhibit lower mass loss, lower surface darkening and lower reduction in tenacity which may be practically useful in imparting desirable softness in jute-cotton union fabric. Treatment with specified cellulase enriched mixed enzyme system (175unit/ $\mathrm{ml}$ of cellulase, $96 \mathrm{unit} / \mathrm{ml}$ of xylanase and $136 \mathrm{unit} / \mathrm{ml}$ of pectinase) on either 1 or $5 \%$ $\mathrm{NaOH}$ pretreated or conventional $2 \% \mathrm{H}_{2} \mathrm{O}_{2}$ bleached jute-cotton union fabric renders a moderate degree of softening action and surface smoothening with overall good balance in important textile related properties. However, higher degree of softening action may be achieved, if the said mixed enzyme treatment is carried out after both sequential pretreatments i.e. $5 \% \mathrm{NaOH}$ pretreatment followed by conventional $\mathrm{H}_{2} \mathrm{O}_{2}$ bleaching at the cost of higher weight loss and reduction in tenacity. Studies on Dyeability of such chemically treated jute-cotton union fabric reveals that $\mathrm{NaOH}$ pretreatment show an increasing trend for acid dye uptake and reactive dye uptake, while all the dilute acid pretreatments show an increasing trend of basic dye uptake in general.
\end{abstract}

Keywords: acid pretreatment, alkali pretreatment, dyeability, $\mathrm{H}_{2} \mathrm{O}_{2}$ bleaching, mixed enzyme treatment, jute-cotton union fabric, softening; abrasion resistance, jute fibre, upholstery, neutralization, non-ionic detergent, humidity, initial modulus, breaking extension, bending length, sasmira stiffness tester
Volume I Issue 2 - 2017

\author{
Ashis Kumar Samanta,' Sunanda Mitra Roy, ${ }^{2}$ \\ Deepali Singhee, ${ }^{3}$ Pubalina Samanta ${ }^{3}$ \\ 'Department of Jute and Fibre Technology, Institute of Jute \\ Technology, University of Calcutta, India \\ ${ }^{2}$ Rani Birla Girls' College, India \\ ${ }_{3}^{3} \mathrm{D}$ Birla Institute, India
}

Correspondence: Ashis Kumar Samanta, IDepartment of Jute and Fibre Technology , Institute of Jute Technology, University of Calcutta, 35 Ballygunge Circular Road, Kolkata 7000I9, India, Email ijtaksamanta@hotmail.com

Received: January 25, 2017| Published: March 09, 2017
Abbreviations: LR, laboratory reagent; EDTA, ethylene diamine tetra acetic acid; MLR, material to liquor ratio; CRA, crease recovery angle; SEM, scanning electron microscopy; DSC, differential scanning calorimetric; DSC, differential scanning calorimetric

\section{Introduction}

A large variety of natural (raw) or conventional $\mathrm{H}_{2} \mathrm{O}_{2}$ bleached jute-cotton union fabrics are commercially being produced either in handloom sector or jute mill sector for its use as upholstery furnishing fabric and other home textiles for its heaviness and unique surface texture. However, the jute-cotton union fabric still suffer some drawbacks ${ }^{1}$ such as high surface roughness with hairs of protruding jute fibres, high fibre shedding from jute component, high stiffness (poor drape) in jute direction, unequal wash shrinkage and unequal dye uptake in two directions, poor crease resistance, poor abrasion resistance, etc. It is expected that the use of jute-cotton union furnishing fabric may further be increased, if some of these drawbacks may be eliminated or partly removed by selective treatments with appropriate chemical or bio-chemical (enzymes) treatments. Some earlier reports are available on $\mathrm{NaOH}$ treatment, ${ }^{2-4}$ acid treatment, ${ }^{5,6}$ enzyme treatment on jute fibre and fabrics for improvement of its relevant fibre/fabric properties. ${ }^{7-9}$ However, such work on jute-cotton union fabric is rare. For jute-cotton union fabric, though a few scanty and sporadic reports are available on softening treatment with alkali, ${ }^{2}$ acid and enzymes ${ }^{10}$ but none is available for acidic pretreatments and / or followed by enzyme treatment. Hence, the present study on the effects of treatment with different dilute acids and dilute alkali $(\mathrm{NaOH})$ on raw jute-cotton union fabric and also on the effects of treatment with cellulase enriched mixed enzymes (mixture of cellulase, xylanase and pectinase) on alkali pretreated, acid pretreated and / or bleached jutecotton union fabric assumes high importance for making the fabric more suited for its end uses as upholstery and furnishing fabric for home textile purposes.

With the above background information and objectives in mind, in the present work, raw (untreated) jute-cotton union fabric has been subjected to treatment with dilute alkali $(\mathrm{NaOH})$, hydrochloric 
acid, formic acid, acetic acid, citric acid and also conventional 2\% $\mathrm{H}_{2} \mathrm{O}_{2}$ bleached jute-cotton union fabric has been treated with specific mixed enzyme system. The effects of such selective chemical and bio-chemical treatments on important textile related properties and surface morphological features of treated jute-cotton union fabric have been evaluated and compared.

\section{Materials and methods}

\section{Materials}

Jute-cotton union fabric: Plain-weave, raw jute-cotton union fabric $(75: 25, \mathrm{w} / \mathrm{w})$ having $280 \mathrm{~g} / \mathrm{m}^{2}$ fabric weight with $80 \mathrm{ends} / \mathrm{dm}, 70$ picks $/$ dm, 42 tex warp (cotton), 185 tex weft (jute), $0.80 \mathrm{~mm}$ thickness and also the same fabric after being desized, scoured and bleached $(260 \mathrm{~g}$ $\mathrm{m}^{2}$ ) were used in the present work.

Chemicals and dyes: Laboratory Reagent (LR) grade hydrogen peroxide $(50 \%)$, Ethylene diamine tetra acetic acid (EDTA), sodium meta silicate, sodium hydroxide $(\mathrm{NaOH})$, hydrochloric acid $(1 \mathrm{~N}$ i.e. $3.6 \% \mathrm{HCl}$ ), citric acid (2-hydroxy-1,2,3-propane tri-carboxylic acid), formic acid $(\mathrm{HCOOH})$, acetic acid $\left(\mathrm{CH}_{3} \mathrm{COOH}\right)$, common salt $(\mathrm{NaCl})$, glauber's salt $\left(\mathrm{Na}_{2} \mathrm{SO}_{4}, 10 \mathrm{H}_{2} \mathrm{O}\right)$, sodium carbonate $\left(\mathrm{Na}_{2} \mathrm{CO}_{3}\right)$, all supplied from M/s E. Merck India was used. Commercial grade non-ionic wetting agent (Lissapol-D) obtained from CIBA-India was also used wherever required. As bio-chemical softening agents, single and mixtures of different ratios of Cell soft, a cellulase enzyme solution (35unit $/ \mathrm{ml}$ ) from M/s Clariant-India, Mumbai, and Bio-cellulase-ZK, a specific mixed enzyme (mixture of $35 \mathrm{unit} / \mathrm{ml}$ of single cellulase enzyme, $96 \mathrm{unit} / \mathrm{ml}$ of xylanase enzyme and $136 \mathrm{unit} / \mathrm{ml}$ of pectinase enzyme) from M/s Biocon-India Ltd, Bangalore, were used. An acid dye, Polar Red-3BN (C.I. Acid Red 131), hot brand reactive dye Procion Green HE-4BD (C.I Reactive Green 19.) and a basic dye Auramine-O (CI Basic Yellow 2) supplied by Modi Dye Chem, Kolkata, were used to evaluate the Dyeability of the fabric samples after the said treatments.

\section{Methods}

Treatment with $\mathrm{NaOH}$ solution: Untreated (raw) jute-cotton union fabric was treated with $1,5,10$ and $18 \%$ aqueous solution of $\mathrm{NaOH}$ using material to liquor ratio (MLR) 1:20 for 30min duration at room temperature $\left(30^{\circ} \mathrm{C}\right)$. The treated fabric was then neutralized by dipping it in $1 \%$ acetic acid solution for $15 \mathrm{~min}$ followed by washing with normal running water before squeezing and final drying in air.

Treatment with dilute acid solutions: Untreated (raw) jute-cotton union fabric was treated with $1 \%$ dilute $\mathrm{HCl}$ (using $1 \mathrm{~N}$. i.e, $3.6 \% \mathrm{HCl}$ solution) or $1 \%$ citric acid, $1 \%$ formic acid and $1 \%$ acetic acid solution for $30 \mathrm{~min}$ at room temperature $\left(30^{\circ} \mathrm{C}\right)$. The treated fabric was then neutralized by dipping it in $1 \%$ sodium hydroxide solution for $15 \mathrm{~min}$ followed by washing with normal running water before squeezing and final drying in air. Observing some odd effects, citric acid treatment was also carried out to investigate the effects of variation in concentrations $(0.5-2 \%)$ of citric acid and treatment periods $(15-20 \mathrm{~min})$.

Desizing, scouring and conventional $\mathrm{H}_{2} \mathrm{O}_{2}$ bleaching: Desizing of jute-cotton union fabric was done employing $20-30 \mathrm{~L} / \mathrm{L}$ of aqueous solution of $3.6 \% \mathrm{HCl}(0.5 \% \mathrm{owf})$ at $60^{\circ} \mathrm{C}$ for $1 \mathrm{~h}$ using laboratory jigger keeping MLR 1:5 (w/w) followed by washing and drying. Desized jute-cotton union fabric was scoured in lab-jigger using $4 \mathrm{~g} / 1$ of soda, $1 \mathrm{~g} / \mathrm{l}$ of non-ionic detergent, using MLR 1:5 at $\mathrm{pH}-8-9$, for $1 \mathrm{~h}$ at $100^{\circ} \mathrm{C}$ followed by repeated washing and drying in air. ${ }^{2,10}$ Untreated (raw) or suitably desized / scoured jute-cotton union fabric was then subjected to conventional $\mathrm{H}_{2} \mathrm{O}_{2}$ bleaching in a lab-jigger using $2 \%$ (owf) $\mathrm{H}_{2} \mathrm{O}_{2}$ , $6 \%$ (owf) sodium meta silicate, $0.7 \%$ (owf) $\mathrm{NaOH}, 0.05 \%$ (owf) EDTA, $0.05 \%$ (owf) non-ionic wetting agent (lissapol-D) at $85^{\circ} \mathrm{C}$ for $2 \mathrm{~h}$ at $p \mathrm{H} 10.5-11.0 .^{2,10,11} \mathrm{The} p \mathrm{H}$ of the bleach-bath was maintained by adding small amount of $1 \% \mathrm{NaOH}$ drop wise. After bleaching, the treated fabric was thoroughly washed under running water, followed by neutralization with $1 \%$ acetic acid solution for $15 \mathrm{~min}$ before further washing with hot and normal running water. Finally, the washed fabric sample was dried in air.

Treatment with single and mixtures of cellulase enzyme and cellulase enriched mixed enzyme: Untreated (raw), $5 \% \mathrm{NaOH}$ pretreated and conventional $2 \% \mathrm{H}_{2} \mathrm{O}_{2}$ bleached jute-cotton union fabric samples were treated separately either with $4 \%$ (owf) overall dosages of ' $\mathrm{Ce}$ llusoft' enzyme (35unit/ml of cellulase), $4 \%$ overall dosages of Bio-cellulase-ZK mixed enzymes (having $35 \mathrm{unit} / \mathrm{ml}$ of cellulase, 96 unit/ $\mathrm{ml}$ of xylanase and $136 \mathrm{unit} / \mathrm{ml}$ of pectinase enzyme) or finally with $4 \%$ (owf) overall dosages of the mixture of varying proportion of ' $\mathrm{Ce}$ llusoft' enzyme and Bio-cellulase-ZK mixed enzyme, so that in the mixture, the cellulase enzyme content of the said cellulase enriched mixed enzyme system varies between 35-210 unit/ml, keeping concentrations of other enzymes constant. All the said enzyme treatments were carried out at $55^{\circ} \mathrm{C}$ for $2 \mathrm{~h}$ at $\mathrm{pH} 4.8-5.0$ (using 1/20th part of sodium-acetate and acetic acid buffer solution) in rotating (with $40 \mathrm{rpm}$ ) beakers using SASMIRA launder-o-meter at optimized conditions of treatment. ${ }^{7,10}$ After the enzyme treatment is over, in each case, the temperature of treatment bath was raised to $90^{\circ} \mathrm{C}$ for $15 \mathrm{~min}$ for de-activation of the enzymes. Finally, the enzyme treated fabric samples were thoroughly washed with normal running water and dried in air.

Dyeing of jute-cotton union fabric with an acid dye: Differently treated and untreated jute-cotton union fabric samples were separately dyed with an acid dye Polar Red-3BN (CI Acid Red-131). For 10g of fabric sample, $0.10 \mathrm{~g}$ of acid dye (for $1 \%$ shade depth) was taken in $200 \mathrm{ml}$ (using material to liquor ratio i.e. MLR 1:20) aqueous solution of $5 \% \mathrm{Na}_{2} \mathrm{SO}_{4}$ and a requisite volume of $2 \% \mathrm{HCOOH}$ solution was added to adjust $\mathrm{pH}$ to 4-4.5 and the dyeing was carried out following a standard method ${ }^{12,13}$ using a laboratory beaker dyeing unit for $1 \mathrm{~h}$ at $90 \pm 5^{\circ} \mathrm{C}$. The dyed samples were then subjected to normal washing, soaping and further washing before drying.

Dyeing of jute-cotton fabric with reactive dye: Differently treated and untreated (raw) jute-cotton union fabric samples were separately dyed at $1 \%$ shade depth using $0.1 \%$ aqueous solution of selected reactive dye (Procion Green HE 4 BD), using a lab beaker dyeing unit maintaining a dyeing temperature of $80 \pm 5^{\circ} \mathrm{C}$ and material to liquor ratio of 1:20 and also using appropriate dose level of sodium chloride $(70 \mathrm{~g} / \mathrm{l})$ and sodium carbonate $(10 \mathrm{~g} / \mathrm{l})$ according to a standard method. ${ }^{12,14,15}$ The dye bath was initially set at $50^{\circ} \mathrm{C}$ with required amount of dye (for $1 \%$ shade) and the pre-wetted fabric sample was put in the dye bath. The temperature was gradually raised to $80-85^{\circ} \mathrm{C}$ and then sodium chloride was added in three installments within $30 \mathrm{~min}$ at an interval of $10 \mathrm{~min}$, keeping the dye bath temperature at $80 \pm 5^{\circ} \mathrm{C}$. Finally, sodium carbonate was added in two installments at $15 \mathrm{~min}$ interval and dyeing was continued for further $45 \mathrm{~min}$. The dyed samples were then subjected to normal washing, soaping and further washing before air drying.

Dyeing of jute-cotton union fabric with a basic dye: Untreated (raw) and differently treated jute-cotton union fabric was dyed with a basic dye using Auramine-O (CI Basic Yellow 2). 10g of the fabric sample was dyed with $0.10 \mathrm{~g}$ of the dye (for $1 \%$ shade depth) in $200 \mathrm{ml}$ 
(MLR 1:20) water at a $\mathrm{pH}$ 5.0-5.5 (the $\mathrm{pH}$ was adjusted using dilute $1 \%$ aqueous solution of $30 \%$ acetic acid) and the dyeing was carried out at $90 \pm 5^{\circ} \mathrm{C}$ for $1 \mathrm{~h}$ using a laboratory beaker dyeing unit following a standard method. ${ }^{12,16}$ After the dyeing was over in each case, the dyed fabric samples were squeezed and subjected to normal washing with hot and normal running water followed by soaping with $2 \mathrm{gpl}$ commercial grade non-ionic detergent (genteel) at $50^{\circ} \mathrm{C}$ for $15 \mathrm{~min}$ and finally washed in normal running water before drying in air

Determination of weight loss or gain and moisture regain: Loss or gain in weight after selective chemical treatment of jute-cotton union fabric was determined by gravimetric principle following oven dry weight method, ${ }^{17,18}$ taking bone dry weights of the samples before and after the treatments and expressing the results as a percentage of the initial bone dry weight of the material taken. The moisture regain of selected bone dried jute-cotton fabric samples were determined according to ASTM-D2654-76 method ${ }^{19}$ by taking the weights before and after conditioning the sample in standard atmospheric conditions $\left(65 \pm 2 \%\right.$ relative humidity and $27 \pm 2{ }^{\circ} \mathrm{C}$ temperature) in a $\mathrm{NaNO}_{3}$ desiccators.

Determination of fabric shrinkage during selective treatments: Linear warp-way and weft-way shrinkage of jute-cotton union fabric samples were determined according to the IS: 2977-1964 method $^{18}$ using the following relationship:

$$
\text { Shrinkage }(\%)=\frac{L_{\circ}-L_{1}}{L_{1}} \times 100
$$

$$
K / S_{\lambda \max }=\frac{\text { Coefficient } \text { of } \text { absorption }}{\text { Coefficient of } \text { scattering }}=\frac{(1-R \lambda \max )^{2}}{2 R_{\lambda} \max }=\alpha C_{d}
$$

Where $\mathrm{K}=$ the co-efficient of absorption, $\mathrm{S}=$ the co-efficient of scattering, $C_{d}=$ the concentration of dye, $R_{\max }=$ the surface reflectance at maximum absorbance wave length $(\lambda \max )$, and $\alpha=\mathrm{a}$ constant.

Whiteness index was determined as per Hunter Lab-

Scale formula, ${ }^{21}$ the yellowness index was determined as per ASTM-E-313-1973 formula ${ }^{22}$ and brightness index was determined as per ISO-2470-(1977) formula ${ }^{23}$ using computer aided Macbeth 2020 Plus reflectance spectrophotometer and associated software using the following relationships:

$$
\begin{aligned}
& \text { Whiteness Index }(\text { Hunter Lab-Scale })=L-3 b=10 \sqrt{ } Y-[21(Y-Z \%)] / \sqrt{ } Y \\
& \text { Yellowness Index }(A S T M-E 313 / 1973)=100(1-B / G)=100\left[1-\frac{0.847 Z}{Y}\right] \\
& \text { Brightness Index }\left(\text { ISO-2470-1977) }=\frac{\text { Reflectance value of the substrate at } 457 \mathrm{~nm}}{\text { Reflectance value of the standard white diffuser } / \text { white tile at } 457 \mathrm{~nm}}\right.
\end{aligned}
$$

where, $\mathrm{X}, \mathrm{Y}$ and $\mathrm{Z}$ are the tristimulus values of the sample, $\mathrm{L}$ is the lightness/darkness indicator in CIE Lab-Scale [L* or simply $\mathrm{L}=16(\mathrm{Y} /$ $\left.Y_{0}\right)^{1 / 3}-16$ as per CIE Lab-1976 formula], $b$ is the blueness/yellowness indicator in the CIE Lab-Scale $\left\{b^{*}\right.$ or simply $b=200\left[\left(\mathrm{Y} / \mathrm{Y}_{\mathrm{o}}\right)^{1 / 3}-(\mathrm{Z} /\right.$ $\left.\left.\left.\mathrm{Z}_{\mathrm{o}}\right)^{1 / 3}\right]\right\}, \mathrm{B}=\mathrm{Z} / 1.181=0.847 \mathrm{Z}, \mathrm{G}=\mathrm{Y}=\mathrm{L}^{2} / 100$ and $\mathrm{X}_{\mathrm{o}}, \mathrm{Y}_{\mathrm{o}}$ and $\mathrm{Z}_{\mathrm{o}}$ are the CIE-tristimulus values for D65 standard illuminant with $10^{\circ}$ standard observer. $^{20}$

Scanning electron microscopy (SEM): The surface morphology of untreated (raw) and selectively treated jute and cotton fibre samples taken out from the corresponding jute yarns and cotton yarns of the untreated (raw) and correspondingly treated jute-cotton union fabrics was examined using JEOL Scanning Electron Microscope (Model: JSM-5200) at an operating voltage of $20 \kappa \gamma$, using a magnification of 1000X. The fibre samples for the SEM study were prepared with Gold-Palladium alloy coating following a standard procedure. ${ }^{24}$

Study of thermal transitions of major jute constituents by DSC-spectral analysis: Differential Scanning Calorimetric (DSC) analysis $^{25}$ of finely crushed (powder) jute fibre samples taken out 
from corresponding untreated (raw) and selectively treated jute-cotton union fabrics were carried out using a Shimadzu differential scanning calorimeter (Model-DSC-50), under flowing nitrogen (flow rate: $50 \mathrm{~cm}^{3} / \mathrm{min}$ ) at a heating rate of $10^{\circ} \mathrm{C} / \mathrm{min}$, using a fixed sample weight of $2 \mathrm{mg}$ over a temperature range from ambient $\left(30^{\circ} \mathrm{C}\right)$ to $500^{\circ} \mathrm{C}$. The fibre samples taken for DSC study were initially washed in running water followed by washing in a mixture of 1:1alcohol-benzene for purification and removal of all impurities/ unreacted chemicals and finally dried in air before crushing them to fine powder taken for DSC study.

\section{Results and discussion}

The effects of treatment with dilute $\mathrm{HCl}$, different concentration of $\mathrm{NaOH}$ solution, specific mixed enzyme system and commonly available chemical softeners and their mixtures on $100 \%$ jute fabrics have been reported in our earlier publication. ${ }^{12}$ Effects of different pretreatments on commercially available mixed enzyme (Biocellulose-ZK, mixture of 35 units $/ \mathrm{ml}$ of cellulase, 96 units $/ \mathrm{ml}$ of xylanase and $136 \mathrm{unit} / \mathrm{ml}$ of pectinase) treatment on jute-cotton union fabric has also been reported ${ }^{10}$ earlier from this laboratory which indicate that action of such mixed enzyme is more on cotton part than jute part on considering the less action on jute, it is thought that either increase in cellulase concentrations in the mixed enzyme or increase in vigorisity of the pretreatment may produce better results. Hence, the present work was undertaken. Citric acid cross-linking on pure jute $^{5}$ and pure cotton fabric ${ }^{22}$ has been reported earlier, but no such report is available for jute-cotton union fabric. Besides, common acid leaching action, citric acid has photo-functional character, ${ }^{6}$ which may also be utilized in chemical modification of jute based fabrics. Hence, in the present work, changes in important textile related properties of jute-cotton union fabric for treatments with different acids (including citric acid), alkali $(\mathrm{NaOH})$ and cellulase enriched specified mixed enzymes have been evaluated and reported. The effects of treatment on bleached jute-cotton union fabric with different chemical softeners and their mixtures as well as different modes of citric acid initiated treatments have also been reported separately as next part of the work.

\section{Effects of acid and alkali treatment}

A comparative evaluation on the changes in property parameters of specific jute-cotton union fabric for simple acid-leaching treatment at room temperature for $30 \mathrm{~min}$ with dilute aqueous solution of different acids $(\mathrm{HCl}$, acetic acid, formic acid and citric acid) indicate that these treatment in general show measurable lowering of tenacity, initial modulus, elongation at break, crease recovery and bending length associated with some enhancement in surface brightness, surface colour strength and basic dye uptake Table 1 except in case of citric acid leaching, where there are some odd effects observed. Dilute $1 \%$ aqueous solution of hydrochloric acid, acetic acid and formic acid treatment at comparable conditions show a mass loss between 1.5 to $2.25 \%$, whereas, $1 \%$ citric acid treatment show a low weight gain of nearly $0.5 \%$. This small weight gain superceding the evident mass loss (due to removal of encrusting intercellular materials and acid dissolvable substances with or without acidic degradation) for citric acid treatment is also associated with relatively lower reduction in bending length, higher loss in tenacity and higher reduction in elongation at break, but causing a higher retention of initial modulus associated with a small but unusual enhancement in total crease recovery angle. These odd-effects observed for citric acid leaching action of jute-cotton union fabric is partly corroborated by the effects observed earlier ${ }^{5}$ for ester-cross linking of citric acid on pure jute fabric. Thus, these odd effects shown by citric acid treatment as compared to other dilute organic or mineral acids can be explained by the possibility of a low extent of self-catalyzed cross linking of citric acid with both cotton or jute cellulose or jute hemicellulose macromolecules, utilizing two - $\mathrm{COOH}$ groups of citric acid (hydroxyl-tri-carboxylic acid) at two ends forming ester cross-link with hydroxyl groups of adjacent cellulose / hemicellulose chains of jute and cellulose chains of cotton. Observed much higher treatment shrinkage in cotton warp direction, in general, is evidently due to higher weaving strain in the warp direction than that in the weft (jute) direction as observed both in case of acid and alkali treatments carried out separately. Effects of alkali $(\mathrm{NaOH})$ treatment on jute ${ }^{26}$ and cotton ${ }^{27}$ are commonly known. However, reports on effect of treatment with different concentrations of $\mathrm{NaOH}$ on jute-cotton union fabric are scanty and sporadic. Effect of alkali $(\mathrm{NaOH})$ pretreatments before $\mathrm{H}_{2} \mathrm{O}_{2}$ bleaching on jute-cotton union fabric has been reported earlier. ${ }^{2}$ Treatment with 1 to $5 \%$ dilute $\mathrm{NaOH}$ solution exhibits 3-6.1\% weight loss with measurable reduction in tenacity, bending length, initial modulus and notable reduction in whiteness index and brightness index showing a surface darkening effect. ${ }^{2}$ While $10-18 \% \mathrm{NaOH}$ pre-treatment on jute-cotton union fabric shows relatively much higher weight loss, higher treatment shrinkage and higher reduction in tenacity, initial modulus, bending length and whiteness/brightness indices associated with notable increase in breaking extension and yellowness index, with much higher surface darkening, Table 1. Though $10-18 \% \mathrm{NaOH}$ pre-treatment makes jute-cotton union fabric much resilient, soft and compact, however, higher weight loss, tenacity loss and surface darkening effect do not encourage employing this treatment as an effective route for softening of jute-cotton union fabric. While $1 \% \mathrm{HCl}$ treatment at $30^{\circ} \mathrm{C}$ for $30 \mathrm{~min}$ offers a low but acceptable degree of softening as well as cleaning action of jute-cotton union fabric with relatively lower weight loss and tenacity loss along with better retention of surface appearance properties showing increased brightness index value as compared to that obtained by dilute $(1-5 \%) \mathrm{NaOH}$ pretreatment, Table 1. The higher weight loss by alkali treatment is believed to be mainly from jute part due to partial dissolution of hemicellulose (having low degree of polymerization $\geq 150$ ) by alkali resulting some loss in tenacity. The small extent of weight loss and reduction in tenacity by $1 \% \mathrm{HCl}$ pretreatment is believed to be due to limited acidic hydrolysis/ degradation of jute cellulose, cotton cellulose and jute hemicellulose. The surface darkening of jute by $\mathrm{NaOH}$ treatment is commonly known due to aerial oxidation ${ }^{2}$ of lignin macro molucules in presence of alkali and cellulose molecules. Surface brightening effect obtained by dilute $\mathrm{HCl}$ treatment is due to removal of metallic cations attached with carboxylic acid group of uronic acid residue present in jute hemicellulose, as well as due to removal of some intercellular encrusting material and jute-batching oil etc.

As citric acid treatment has shown some interesting and odd effects, the effect of citric acid treatment on jute-cotton union fabric has been further examined to examine the effects of citric acid treatment on jute-cotton union fabric using varying concentrations of citric acid for varying treatment period. The observed results, shown in Table 2 indicate that either with increase in concentrations of citric acid $(0.5-2 \%)$ for fixed period of treatment time (30min) or with increase in treatment time (15-120min) for fixed concentration (1\% aqueous solution) of citric acid, there are small but measurable weight gain along with an increasing trend in reduction of tenacity, elongation at break associated with some enhancement increase recovery angle and 
surface colour strength as well as measurable increase in basic dye uptake. Observed enhancement increase recovery angle and a less reduction in bending length with relatively higher retention of initial modulus may be viewed as a consequent effect of possible low extent of self-catalyzed crosslink formation between the two - $\mathrm{COOH}$ groups of the citric (tri-carboxylic) acid and adjacent cellulose chains of cotton and cellulose or hemicellulose chains of jute. While obvious influence of limited degradation of cellulose and hemicellulose polymer chain of both jute and cotton by low extent of acidic hydrolysis at room temperature using different concentrations and different treatment durations cannot be precluded. Hence, the observed effects Table 2 may be viewed as resultant combination of the above said two opposing influences.

\section{Effects of treatment with single and mixture of cellula- se enzyme and cellulase enriched mixed enzyme}

Enzyme assisted softening and bio-polishing of $\operatorname{cotton}^{28}$ fabric by cellulase enzyme is common and well known. Treatment of jute fabric using mixed enzymes ${ }^{7}$ (mixture of cellulose, xylanase and pectinase) has also been reported in recent past. Due to presence of three dimensional network of lignin macro-molecule in jute, action of cellulase enzyme is found to be retarded. ${ }^{7}$ Hence, to enhance the action of enzymes in jute substrate, along with desirable extent of enzymatic hydrolysis of cellulose part, the hemicellulose (xylan) part and residual small amount of pectin part of jute, it has been modified with mixed enzymes containing cellulase, xylanase and pectinase enzymes with varying concentrations of cellulase enzyme. Our earlier work indicate that requirement of cellulase enzyme concentration is more for jute substrate than that required for cotton substrate for same level of weight loss (i.e. action of cellulase enzyme is much higher in cotton than that in jute..$^{10}$ Earlier studies also indicate that application of $4 \%(0 \mathrm{wf})$ dose of commonly available mixed enzyme (35 unit $/ \mathrm{ml}$ of cellulase, $96 \mathrm{unit} / \mathrm{ml}$ of xylanase and $136 \mathrm{unit} / \mathrm{ml}$ of pectinase) at specified treatment conditions (Temp-55 ${ }^{\circ} \mathrm{C}$ pH-4.8-5.0, time $2 \mathrm{~h}$, MLR $1: 20)$ on either dilute alkali $(1-5 \% \mathrm{NaOH})$ pretreated or conventionally scoured and per-oxide bleached jute ${ }^{7}$ and jutecotton union fabrics ${ }^{10}$ offers somewhat better softening action. Our very recent work $^{12}$ indicates that the softening action may further be enhanced on jute fabric by increase of cellulase concentration in such mixed enzyme system. In all such cases, the action of said mixed enzymes is found to be better than application of lone cellulase enzyme for equivalent dosages of treatment under comparable conditions of treatment. Thus, it is thought that a cellulase enriched mixed enzymes may be more useful for better action on jute-cotton union fabric. For presence of more easily accessible cotton part (in varying weight) and less accessible jute part in different varieties of jute-cotton union fabrics, the necessary correct proportions of cellulase: xylanase: pectinase enzymes for application of such cellulase enriched mixed enzymes need to be separately evaluated and optimized. Hence, in the present study, cellulase enriched mixed enzyme (with varying cellulase enzyme content) has been applied both on alkali pretreated and conventionally scoured and $\mathrm{H}_{2} \mathrm{O}_{2}$ bleached jute-cotton union fabric. The observed results, shown in Table 3 indicate that keeping the concentrations of xylanase and pectinase enzyme constant, with increase in concentrations of cellulase enzyme in the mixture, the weight loss, treatment shrinkage, breaking elongation, crease recovery, brightness and whiteness index as well as dye-ability (with acid dye) of jute-cotton union fabric gradually increases while initial modulus, tenacity, stiffness, yellowness index and dye uptake with reactive dye uptake gradually reduces. An acceptable level of softening with desirable balance in other textile related properties are thus obtained with $175 \mathrm{unit} / \mathrm{ml}$ of cellulose, $96 \mathrm{unit} / \mathrm{ml}$ of xylanase and $136 \mathrm{unit} / \mathrm{ml}$ of pectinase applied on either $5 \% \mathrm{NaOH}$ pretreated or $2 \% \mathrm{H}_{2} \mathrm{O}_{2}$ bleached jute-cotton union fabric Table 4. Among the two pretreatments, $\mathrm{H}_{2} \mathrm{O}_{2}$ bleaching prior to such cellulase enriched mixed enzyme treatment offers a better balance in all respect. The observed changes in the property parameters of jute-cotton union fabric are the outcome of the enzyme assisted hydrolysis of corresponding jute and cotton constituents. However, the softening action so obtained even by application of the said cellulase enriched mixed enzymes on $\mathrm{H}_{2} \mathrm{O}_{2}$ bleached jute-cotton union fabric is not up to the desired level (as compared to the level of enzyme assisted softness available in pure cotton fabric. Hence, the effectiveness of application of different single and mixture of chemical softeners on bleached jute-cotton union fabric has also been studied and reported separately. Acidic pretreatment (using $1 \% \mathrm{HCl}$ or $1 \%$ citric acid) before $2 \% \mathrm{H}_{2} \mathrm{O}_{2}$ bleaching, however, cannot produce desirable softening or surface smoothening action by either single cellulase enzyme treatment or by treatment with specified cellulase enriched mixed enzyme as compared to that obtained by $5 \% \mathrm{NaOH}$ pretreatment followed by $2 \% \mathrm{H}_{2} \mathrm{O}_{2}$ bleaching of the same fabric followed by mixed enzyme treatment.

\section{Study of surface morphology}

Figure 1 shows scanning electron micrographs \{Micrographs a-h for Jute fibres and Micrographs a'-h' for cotton fibres showing the surface morphology of raw, untreated and differently treated jute and cotton fibres taken out from untreated and correspondingly treated jute-cotton union fabrics. Comparison of micrographs (a) and (a'), Figure 1, (for multicellular raw, untreated jute and convulated unicellular cotton respectively) with micrographs b-e and b'-e', (for differently acid treated jute and cotton fibres respectively), Figure 1, show different degree of surface leaching and cleaning action on both the fibre, along with causing some degree of surface etching on jute. Micrographs-b and b', Figure 1, for $1 \% \mathrm{HCl}$ treated jute and cotton substrate show higher degree of surface leaching action causing some low degree of acidic degradation along with removal of some encrusting intercellular or intra-cellular materials from both jute and cotton respectively. Specifically to mention, the said leaching out action by $1 \% \mathrm{HCl}$ treatment shows some higher degree of surface damage with distinct separation of filaments in jute as well as creating some degree of surface irregularities on cotton, as compared to much less severe action by other acid treatment on both jute and cotton. Both the micrographs e and e', Figure 1, respectively for $1 \%$ citric acid treated raw jute fibre and raw cotton fibres show almost similar level leaching action with almost no surface etching, coupled with minor or almost no weight loss Table 2 on both jute and cotton fibres unlike the effects of other acids on the same. At the same time, there has been some powdery deposits on both jute and cotton fibre surface (more in cotton and less in jute) probably due to the anchoring of some citric acid residue by possible self catalytic cross-linking. Both the micrograph- $f$ and $f$ ', Figure 1 , for $5 \% \mathrm{NaOH}$ treated jute and cotton fibre respectively show an increase in fibre diameter by alkaline swelling with a compact rod like appearance of fibre strands in both the fibres. However, the surface appearance of alkali treated jute fibre appears to be a bit darker than the raw or any of the acid treated jute, while, $5 \% \mathrm{NaOH}$ treated cotton shows some degree of deconvulation (not complete) after the alkaline swelling. Micrographs- $g$ and g', 
Figure 1, for $2 \% \mathrm{H}_{2} \mathrm{O}_{2}$ bleached jute and cotton substrate further treated with $4 \%$ (owf) cellulase enriched mixed enzyme show higher surface smoothening and cleaning action, without any rod like appearance. Micrographs-h and h', Figure 1, for both the sequentially pretreated ( $5 \% \mathrm{NaOH}$ pretreatment followed by $2 \% \mathrm{H}_{2} \mathrm{O}_{2}$ bleaching) jute and cotton fibres subjected to $4 \%$ (owf) cellulase enriched mixed enzyme treatment show higher surface smoothening and cleaning action for both the fibres.

A comparison of changes in surface appearance and yarn diameter and inter yarn spaces and woven fabric structure for Jute fabrics and
Jute-Cotton Union Fabrics for the above said different treatments (Acid i.e, $\mathrm{HCl}$ treatment, Alkali i.e, $5 \% \mathrm{NaOH}$ treatment, Cellulase enriched mixed Enzyme treatment etc) is shown in Figure 1, which clearly indicates that most of the treatment causes surface leaching and cleaning of the fabrics creating more and more inter yarn spaces making it more breathable and also improving drape and feel except $5 \% \mathrm{NaOH}$ alkali treatment, which due to swelling and higher length wise shrinkages of yarns, the diameter of both Jute and Cotton yarns become increased and more jam structure of fabric is obtained, which however is loosened again by subsequent cellulose enriched mixed enzyme treatment.

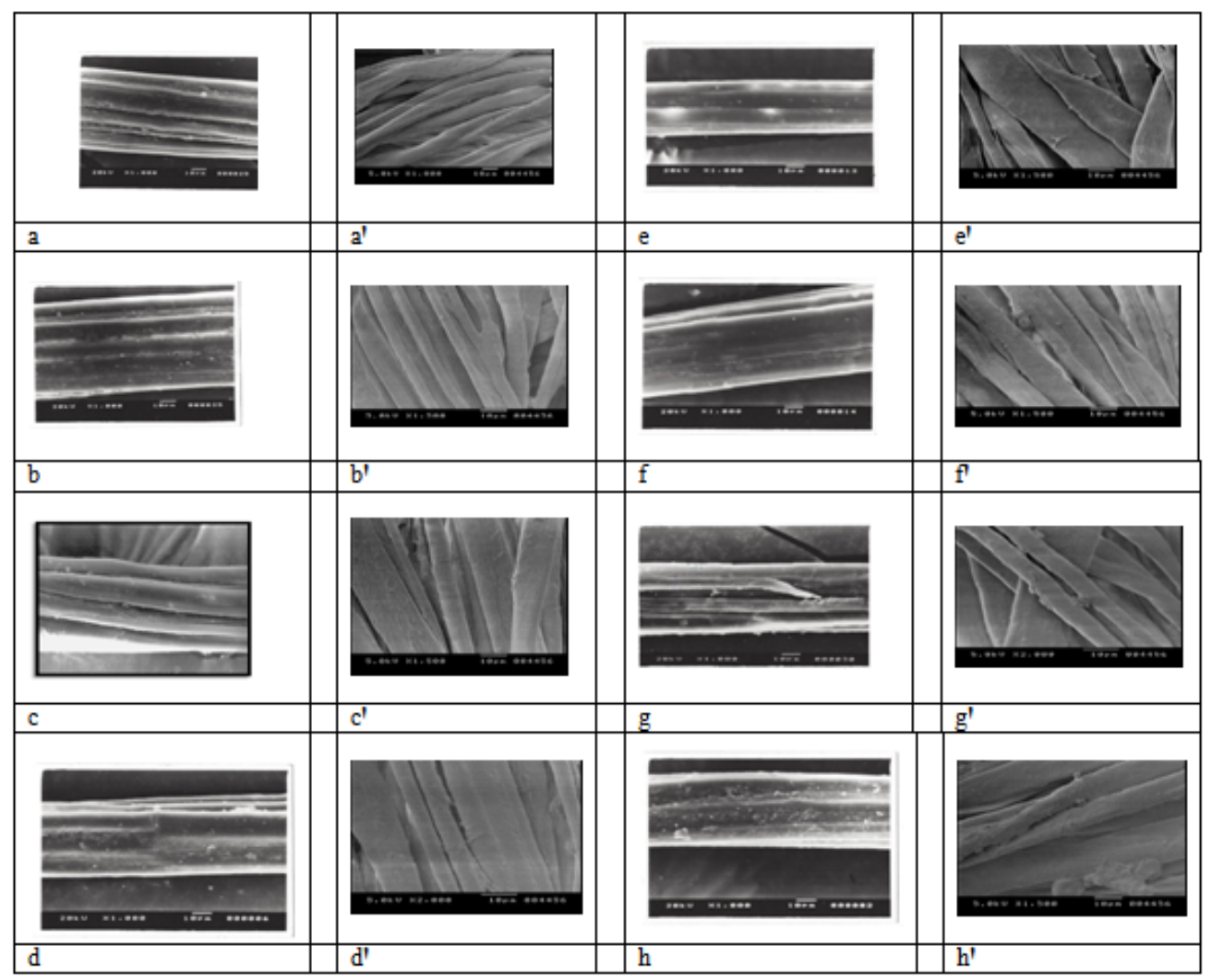

Figure 1 SEM for Jute (a-h) and Cotton (a' - h'): SEM photographs of(a)Untreated (raw) jute fibre; (a') Untreated (raw) cotton fibre; (b) $1 \%$ HCl treated raw jute fibre; (b') $1 \% \mathrm{HCl}$ treated (raw) cotton fibre; (c) $1 \%$ acetic acid treated raw jute fibre; (c') $1 \%$ acetic acid treated raw cotton fibre; (d) $1 \%$ formic acid treated raw jute fibre; (d') $1 \%$ formic acid treated raw cotton fibre;(e) $1 \%$ citric acid treated raw jute fibre; (e') $1 \%$ citric acid treated raw cotton fibre; (f) $5 \% \mathrm{NaOH}$ treated raw jute fibre; (f') $5 \% \mathrm{NaOH}$ treated raw cotton fibre.(g) $5 \% \mathrm{NaOH}$ pretreated raw jute fibre further treated with $4 \%$ (owf) cellulase enriched mixed enzyme (using mixture of $175 \mathrm{unit} / \mathrm{ml}$ cellulase, $96 \mathrm{unit} / \mathrm{ml}$ xylanase and $136 \mathrm{unit} / \mathrm{ml}$ pectinase); (g') $5 \% \mathrm{NaOH}$ pretreated raw cotton fibre further treated with $4 \%$ (owf) cellulase enriched mixed enzyme (h) Jute pretreated with $5 \% \mathrm{NaOH}$ followed by $2 \mathrm{oH}_{2} \mathrm{O}_{2}$ bleaching and subsequently treated with $4 \%$ cellulase enriched specific mixed enzyme; and ( $h$ ') Cotton pretreated with $5 \% \mathrm{NaOH}$ followed by $2 \% \mathrm{H}_{2} \mathrm{O}_{2}$ bleaching and subsequently treated with $4 \%$ cellulase enriched specific mixed enzyme.

\section{Study of thermal transition of major jute constituents}

Figure 2 shows Differential Scanning Calorimetric (DSC) thermo grams of differently acid/ alkali and enzyme treated jute fibres taken out from the corresponding treated jute-cotton union fabrics, showing the relative changes in thermal stability of major jute constituents indicating the relative degree of attack/ damage in the corresponding jute constituents by each treatment.

DSC thermo gram a, Figure 2, for untreated raw jute show two endotherms at $78^{\circ} \mathrm{C}$ and $364^{\circ} \mathrm{C}$ (corresponding to evaporation of observed moisture and thermal degradation of jute-cellulose respectively) and two broader exotherms at $293^{\circ} \mathrm{C}$ and $425^{\circ} \mathrm{C}$ (corresponding to the thermal degradation of hemicellulose and lignin component of jute respectively). ${ }^{25}$ Comparison of DSC thermo grams $\mathrm{b}$ to f, Figure 2, for differently acid and alkali treated jute with DSC thermo gram a, Figure 2, for untreated raw jute, indicate that dilute $\mathrm{HCl}$ and dilute acetic acid treatment (thermo grams b and d respectively, Figure 2) do not alter the thermal degradation temperature of cellulose component while the hemicellulose component in both the cases degrades at around $330^{\circ} \mathrm{C}$ instead of $293^{\circ} \mathrm{C}$ (for raw jute) and lignin component in both the cases degrades at $400^{\circ} \mathrm{C}$ instead of $425^{\circ} \mathrm{C}$ (for raw jute). The early degradation of lignin may be explained by relatively higher damage of the same by acidic attack on lignin macromolecules by these two acids. The higher thermal stability of hemicellulose may be viewed as the result of refining action of these two acids by dissolution and removal of some unbound lower 
molecular weight fraction of hemicellulose present in jute, while, the cellulose part remain almost unaffected. Thus, DSC thermo gram c, Figure 2, for formic acid treated jute show thermal degradation of hemicellulose component at two zones at $\left(293^{\circ} \mathrm{C}\right.$ and $\left.339^{\circ} \mathrm{C}\right)$ and also the thermal degradation of the lignin component at two zones (at $390^{\circ} \mathrm{C}$ and $450^{\circ} \mathrm{C}$ ). For very low molecular weight formic acid, it may be possible to diffuse rapidly into the interior of non-crystalline zone up to the crystalline edge of jute macromolecules and can facilitate segregation of both the hemicellulose and lignin components of jute into the respective lower and higher molecular weight fragments resulting thermal degradation of both the components at two different zones. These acid treatments in general do not alter or affect the thermal degradation of temperature of cellulose component, having relatively higher degree of polymerization, mostly located in crystalline and edge of the para crystalline zone. DSC thermo gram e, Figure 2, for $1 \%$ citric acid treated jute show an increase in thermal stability of all the major constituents of jute (hemicellulose, cellulose and lignin) showing their thermal degradation at $307^{\circ} \mathrm{C}, 377^{\circ} \mathrm{C}$ and $440^{\circ} \mathrm{C}$ respectively. Despite some degree of acidic refining and cleaning action, citric acid perhaps forms a low degree of self catalyzed ester crosslink with jute -cellulose or hemicellulose showing a small but measurable increase in thermal stability of all the three major components, where formation of citric acid-cellulose, citric acid-hemicellulose and even citric acid-lignin cross-links cannot be precluded. Moreover, in this case, higher thermal stability of hemicellulose component may be also due to refining and dissolution of lower fragments of hemicellulose in addition to the possible effect of a low degree of crosslink formation. DSC thermo gram $\mathrm{f}$, Figure 2, for $5 \% \mathrm{NaOH}$ treated jute also show an increase in the thermal degradation temperature of hemicellulose component along with some reduction in the thermal degradation temperature of cellulose component and also show the thermal degradation of lignin component at two zones (at $396^{\circ} \mathrm{C}$ and $450^{\circ} \mathrm{C}$ ). These observed changes in thermal degradation temperature of all the three major component of jute after $5 \% \mathrm{NaOH}$ treatment is believed to be perhaps due to the combined influence of refining and dissolution of hemicellulose component of jute as well as breakages of some lignin-hemicellulose and cellulose-hemicellulose inter unit linkages by alkaline hydrolysis. DSC-thermo gram g, Figure 2, sequential pretreated $\left(5 \% \mathrm{NaOH}\right.$ pretreated and $2 \% \mathrm{H}_{2} \mathrm{O}_{2}$ bleached) jute further subjected to $4 \%$ (owf) cellulose enriched mixed enzyme, show the moisture evaporation endotherm at relatively lower temperature $\left(68^{\circ} \mathrm{C}\right)$ indicating a much open structure of the jute fibre caused due to both the alkaline hydrolysis and the oxidative degradation followed by enzymolytic hydrolysis; causing easy evaporation of moisture at lower temperature. Corresponding thermal degradation exotherms of the same for hemicellulose part are observed at two zones $\left(293^{\circ} \mathrm{C}\right.$ and $365^{\circ} \mathrm{C}$ ), the thermal degradation endotherms for cellulose part also occur at two zones $\left(330^{\circ} \mathrm{C}\right.$ and $\left.377^{\circ} \mathrm{C}\right)$ and the thermal degradation exotherms for lignin part occur at two zones $\left(389^{\circ} \mathrm{C}\right.$ and $\left.425^{\circ} \mathrm{C}\right)$, indicating that all the major constituents of jute fibre are affected by these three sequential treatments including enzymolytic hydrolysis causing breakages of inter-unit linkages and glycosidic linkages splitting all the three major constituents of jute into two fragments of low and high molecular weight fractions. Thus, the above said DSC thermo grams show a clear understanding of the nature of physicochemical changes and relative degree of chemical attack on the three major constituents of jute, by the said acid, alkali and mixed enzyme treatments.

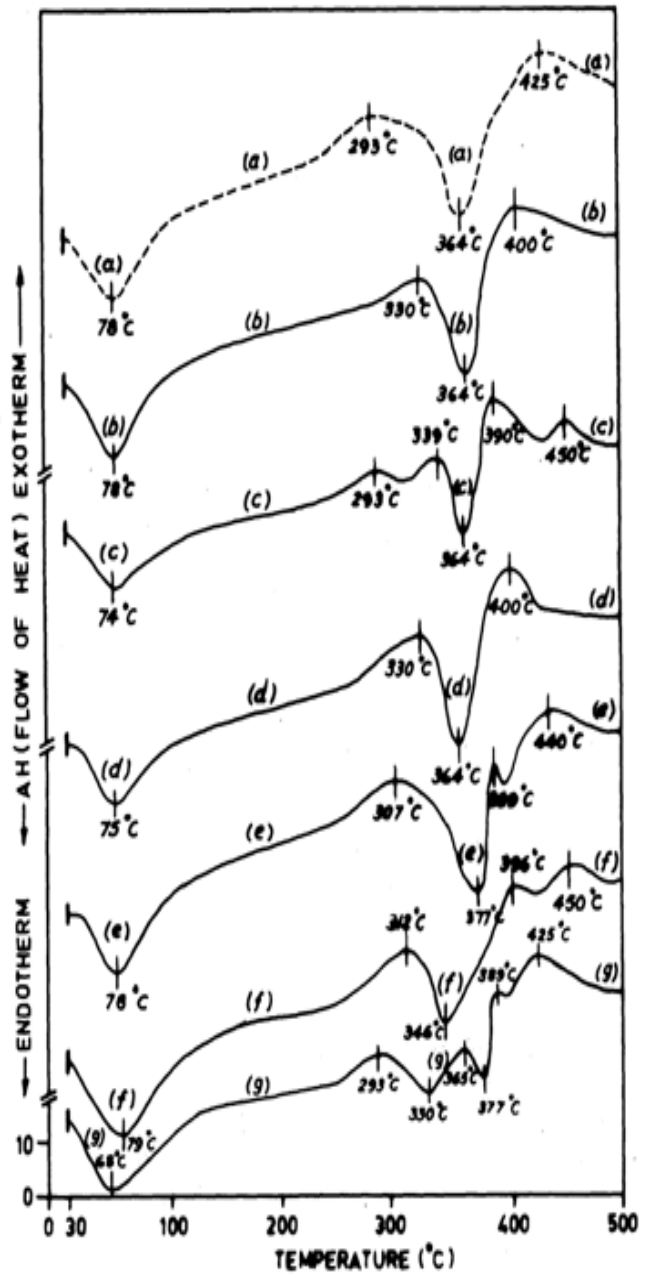

Figure 2 DSC thermo grams of different organic / mineral acid treated, alkali treated and specific mixed enzyme treated jute fibre taken out from jute-cotton fabric: (a) Raw (untreated) jute, (b) Dilute (1\%) $\mathrm{HCl}$ treated jute, (c) Dilute (1\%) Formic acid treated jute, (d) Dilute (1\%) acetic acid treated jute, (e) Dilute (1\%) Citric Acid treated jute, (f) $5 \% \mathrm{NaOH}$ treated jute and (g) sequential pretreated $\left(5 \% \mathrm{NaOH}\right.$ pretreated and $2 \% \mathrm{H}_{2} \mathrm{O}_{2}$ bleached) jute further subjected to $4 \%$ (owf) cellulose enriched mixed enzyme treatment.

\section{Conclusion}

Treatment with aqueous solution of $10-18 \% \mathrm{NaOH}$ (at $30^{\circ} \mathrm{C}$ for 30min) makes jute-cotton union fabric much resilient, soft and compact with measurable reduction in bending length and tenacity with noticeable increase in breaking extension and dye uptake for both acid dye and reactive dye. However, the same is associated with high mass loss, tenacity loss, surface darkening (browning) effect. Whereas, treatment with $5 \% \mathrm{NaOH}$ solution offers a more desirable balance between degree of softening and overall textile related properties of jute-cotton union fabric.

Treatment with $1 \%$ aqueous solution of $\mathrm{HCl}\left(\right.$ at $30^{\circ} \mathrm{C}$ for $\left.30 \mathrm{~min}\right)$ offers much lower degree of softening but much higher surface brightening action on jute-cotton union fabric with relatively much lower mass loss and tenacity loss as compared to those obtained by either $5 \%$ or $10-18 \% \mathrm{NaOH}$ pre-treatment of the same. 
Among the treatments with different organic acids (acetic acid, formic acid and citric acid), 1-2\% citric acid treatment interestingly shows an odd effect showing no weight loss and rather small weight gain with less reduction in bending length, some increase in crease recovery angle and relatively higher retention of initial modulus, surpassing the effects of mass loss due to acidic refining / cleaning and degradation.

SEM study confirms that the surface cleaning action and leaching out action is highest in case of $1 \% \mathrm{HCl}$ treatment, while, $1 \%$ citric acid treatment shows some powdery deposition of some granular materials on the fibre surface, the later may be due to partial anchorage of some citric acid molecules by self catalyzed cross linking. DSC study reveals that the all major constituents of jute after citric acid treatment show an increase in thermal stability.

Study on effect of treatment with a specific dosage of cellulase enriched mixed enzyme (having specified proportions of cellulase, xylanase and pectinase enzymes) led to conclude that either 5\% $\mathrm{NaOH}$ pretreatment or $2 \% \mathrm{H}_{2} \mathrm{O}_{2}$ bleaching action before the said mixed enzyme (mixture of $175 \mathrm{unit} / \mathrm{ml}$ of cellulase, $96 \mathrm{unit} / \mathrm{ml}$ of xylanase and 136 unit/ml of pectinase enzymes) treatment render the corresponding jute-cotton union fabric a better balance in textile related property parameters except the observed reduction in tenacity and reactive dye uptake. Dilute acidic pretreatments (by $\mathrm{HCl}$ and Citric acid) prior to $\mathrm{H}_{2} \mathrm{O}_{2}$ bleaching cannot produce desirable effects after specified cellulase enriched mixed enzyme treatment as compared to that obtained by $5 \% \mathrm{NaOH}$ pretreatment followed by $2 \% \mathrm{H}_{2} \mathrm{O}_{2}$ bleaching before such mixed enzyme treatment depending on the condition of pretreatments prior to the said mixed enzyme treatment. Highest degree of softening of jute-cotton union fabric is obtained if the said mixed enzyme treatment is carried out after both the $5 \% \mathrm{NaOH}$ pretreatment and $2 \% \mathrm{H}_{2} \mathrm{O}_{2}$ bleaching carried out in sequence, but the same associated with relatively higher mass loss and reduction in tenacity.

\section{Acknowledgments}

None.

\section{Conflict of interest}

Author declares there is no conflict of interest in publishing the article

\section{References}

1. Ghosh P, Samanta AK, Das D. Effect of selective pretreatments and different resin post-treatments on jute-viscose upholstery fabric. Indian $J$ Fibre Text Res. 1994;19(4):277-285.

2. Ghosh P, Samanta AK. Effect of selective pretreatments and subsequent $\mathrm{N}$-methylol-acrylamide resin post-treatment on jute/cotton union furnishing fabric. Indian J Fibre Text Res. 1996;21(2):131-139.

3. Ganguly PK, Sur D, Mukhopadhyay AK. Mechanical behaviour of chemically texturized jute fabric. Indian J Fibre Text Res. 1995;20(2):86-91.

4. Chakraborty SK, Ghosh BS, Adhikari D, et al. Brightening of grey jute-Mechanism and application. Indian $J$ Fibre Text Res. 1995;20(3):156-160.

\section{Ghosh P, Das D, Samanta AK. J Polym Mat. 1995;12:297.}

6. Gangopadhyay R, Ghosh P. Photofunctionalization of cellulose and lignocellulose fibres using photoactive organic acids. European Polym J. 2000;36(3):625-634.
7. Chattopadhaya SN, Day A, SK Sanyal, Kundu AB, Pan NC, et al. Indian Text J. 1997;107:14.

8. Ghosh BL, Dutta AK. The enzymatic softening and upgrading of lignocellulosic fibres part I: the softening and cleaning of low-grade mesta and jute. J Text Inst. 1980;71(2):108-116.

9. Dutta AK, Ghosh BL, Aditya RN. The enzymatic softening and upgrading of lignocellulosic fibres: part iii: pre-treatment of jute with enzymes for fine-yarn spinning. J Text Inst. 2000;91(1):28-34.

10. Samanta AK, Singhee D, Basu G, et al. Effect of selective pretreatments and subsequent mixed enzyme treatment on properties of jute-cotton union fabric. Indian J Fibre Text Res. 2005;30(4):451-467.

11. Samanta AK, Singhee D, Basu G, et al. Hydrogen peroxide and potassium per-oxo-disulphate combined room temperature bleaching of jute, cotton and jute-cotton union fabrics-An energy-efficient ecofriendly process. Indian J Fibre Text Res. 2007;32(2):221-231.

12. Samanta AK, Mitra S, Mahalanabis KK. J Inst of Engg (India). Text Engg. 2006;86:21.

13. Ghosh P, Dev D, Samanta AK. Graft copolymerization of acrylamide on cotton cellulose in a limited aqueous system following pretreatment technique. J Appl Polym Sc. 1995;58(10):1727-1734.

14. Ghosh P, Samanta AK, Basu G. Effect of selective chemical treatments of jute fibre on textile-related properties and processibility. Indian J Fib Text Res. 2004;29(1):85-99.

15. Das D, Samanta AK, Dasgupta PC. Reactive dyeing behaviour of ramie fabrics pretreated with different swelling agents and their rub fastness property. Indian J Fibre Text Res. 1997;22(1):53-60.

16. Ghosh P, Datta C. Indian J Tech. 1987;25:681

17. Knox BH, Weigmann HD, Scott MG. The Effects of an Aqueous Medium on the Structure and Physical Properties of a Polyester Yarn. Text Res J. 1981;51(8):549-558.

18. ISI (BIS) Hand Book of Textile Testing SP-15-1981 (Bureau of Indian Standard), New Delhi, India, p. 221, 229, 255, 280, 587.

19. Annual Book of ASTM Standards Part-321: 23.02. American Society for Testing and Materials. Philadelphia, Pennsylvania, USA; 1976. p. 219.

20. Shah HS, Gandhi RS. Instrumental colour Measurement and Computer Aided Colour Matching for Textiles. Mahajan Book Distributors, India; 1990.

21. Hunter RS. Measurement of Appearance. New York: Inter Science Publishers; 1975. p. 174.

22. Annual Book of ASTM Standards E 12.02 ASTM-E-313-1973. American Society for Testing and Materials. Philadelphia; 1974. p. 225.

23. International Standard Specification: ISO: 2470 \& ISO: 2469. International Organization for standardization. Switzerland; 1977. p. 1.

24. Guha Roy TK, Mukhopadhyay AK, Mukherjee AK. Surface Features of Jute Fiber Using Scanning Electron Microscopy. Text Res J. 1984;54(12):874-882.

25. Ghosh P, Samanta AK, Dev D. Simultaneous free radical polymerization and acidic polycondensation of acrylamide-formaldehyde resin on jute fabric. J Appl Polym Sc. 1997;64(13):2473-2489.

26. Chakravarty AC. Crimp Produced in Jute Fibers by Treatment with Solutions of Sodium Hydroxide. Text Res J. 1962;32(6):525-526.

27. Mersh JT. Mercerising. Messers Chapman and Hall Ltd, London; 1941 p. 458.

28. Klahorst S, Kumar A, Mullins MM. Colourage. 1997. p. 29.

29. Samanta AK, Sunanda M, Deepali S, et al. Journal of Materials. 2015;1(4):111-122. 